\title{
Karakteristik Kimia dan Morfologi dari Total Suspended Particulate (TSP) di Jakarta dan Puncak-Bogor pada Masa Pembatasan Sosial Berskala Besar
}

\section{Chemical and Morphological Characteristics of Total Suspended Particulate (TSP) in Jakarta and Puncak-Bogor during the Period of Large-Scale Social Restrictions}

\author{
Muharam Syam Nugraha ${ }^{1 *}$, Asep Saefumillah ${ }^{1}$, dan Ardhasena Sopaheluwakan ${ }^{2}$ \\ ${ }^{1}$ Program Studi Ilmu Kimia, Fakultas Matematika dan Ilmu Pengetahuan Alam, Universitas Indonesia, Jl. \\ Lingkar Kampus Raya, Kota Depok, Kode pos: 16424, Indonesia \\ ${ }^{2}$ Pusat Informasi Layanan Iklim Terapan, Badan Meteorologi Klimatologi dan Geofisika, Jl. Angkasa I No. 2 \\ Kemayoran, Jakarta Pusat, Kode pos: 10610, Indonesia \\ *Email: muharam.syam@ui.ac.id
}

Diterima 8 Oktober 2021, direvisi 12 November 2021, disetujui 19 November 2021

\begin{abstract}
ABSTRAK
Karakteristik Kimia dan Morfologi dari Total Suspended Particulate (TSP) di Jakarta dan PuncakBogor pada Masa Pembatasan Sosial Berskala Besar. Penggunaan transportasi umum di DKI Jakarta selama pemberlakuan Pembatasan Sosial Berskala Besar (PSBB) periode April-Mei 2020 meningkatkan kualitas udara secara signifikan, dibandingkan dengan tahun 2019. Salah satu parameter yang dapat menentukan kualitas udara adalah Total Suspended Particulate (TSP). Sampel TSP dikumpulkan dari lokasi Jaringan Pemantau Kualitas Udara Badan Meteorologi, Klimatologi, dan Geofisika (BMKG) di Stasiun Meteorologi Kemayoran-Jakarta dan Pos Polusi Udara Cibeureum, Puncak-Bogor menggunakan alat High Volume Air Sampler (HVAS) selama 24 jam. Periode pengambilan sampel setiap enam hari sekali mulai 14 Maret hingga 19 Mei 2020. Konsentrasi TSP ditentukan menggunakan metode gravimetri. Rata-rata konsentrasi TSP pada tiga periode sampling pertama April 2020 (menjelang dan awal berlakunya PSBB) memiliki nilai terendah di Jakarta dan Puncak-Bogor berturut-turut sebesar $80,08 \mu \mathrm{g} / \mathrm{m}^{3}$ dan $40,51 \mu \mathrm{g} / \mathrm{m}^{3}$. Tingkat potensi toksisitas ditentukan untuk mengetahui efeknya terhadap kesehatan manusia. Potensi toksisitas dihitung dengan membagi konsentrasi TSP dengan nilai baku mutu nasional sebesar $230 \mathrm{ug} / \mathrm{m}^{3}$. Nilai potensial toksisitas rata-rata di Jakarta dan Puncak-Bogor masingmasing sebesar 0,527 dan 0,220. Sumber asal materi partikulat diketahui dengan digunakan model pollution-rose. Sampel TSP dikarakterisasi menggunakan instrumen Scanning Electron Microscopy (SEM). Unsur yang melimpah pada permukaan partikel, secara berurutan terdiri dari $\mathrm{O}, \mathrm{Si}, \mathrm{C}, \mathrm{Na}$, $\mathrm{Al}, \mathrm{K}$ dan $\mathrm{Ca}$. Rasio komponen (Ca, $\mathrm{C}, \mathrm{O}, \mathrm{Na}, \mathrm{Al}, \mathrm{Si}$, dan $\mathrm{K}$ ) yang terdapat pada sampel TSP dari Jakarta dan Puncak-Bogor masing-masing sebesar 1,303; 1,060; 1,026; 0,995; 0,969; 0,898; dan 0,882. TSP dari Puncak-Bogor memiliki morfologi dengan bentuk cenderung tidak beraturan, sedangkan TSP dari Jakarta cenderung berbentuk bulat yang bertumpuk. Berdasarkan morfologi dan analisis kimianya, sebagian besar sumber TSP di Puncak-Bogor berasal dari alam, sedangkan TSP di Jakarta berasal dari campuran partikulat sumber antropogenik.
\end{abstract}

Kata kunci: TSP, pollution-rose, Scanning Electron Microscope (SEM), morfologi, antropogenik.

\section{ABSTRACT}

Chemical and Morphological Characteristics of Total Suspended Particulate (TSP) in Jakarta and Puncak-Bogor during the Period of Large-Scale Social Restrictions. The utilization of public transport 
utilization in DKI Jakarta during the implementation of Large-Scale Social Restrictions (PSBB) in the period of April - May 2020 significantly improved the air quality, compared to 2019. One of the parameters for determining air quality is total suspended particulates (TSP). TSP samples were collected from the sites of Air Quality Monitoring Network of the Meteorology, Climatology and Geophysics Agency (BMKG) at Kemayoran-Jakarta Meteorological Station and Cibeureum Air Pollution Post in Puncak-Bogor using a High Volume Air Sampler (HVAS) for 24 hours. The sampling period is every six days during March 14 to May 19,2020. TSP concentration was determined by gravimetric method. The average TSP concentration in the first three sampling period of April 2020 (before and the beginning of PSBB enactment) had the lowest values in Jakarta and Puncak-Bogor at $80.08 \mu \mathrm{g} / \mathrm{m} 3$ and $40.51 \mu \mathrm{g} / \mathrm{m}^{3}$, respectively. Level of potential toxicity is determined to figure out its effect on human health. Potential toxicity is calculated by dividing TSP concentration with the national quality standard value (230 ug/ $m^{3}$ ). The average toxicity potential value in Jakarta and Puncak-Bogor is 0.527 and 0.220, respectively. To determine the source of particulate matter, a simple pollution-rose model was used. TSP samples were characterized using Scanning Electron Microscopy (SEM) instrument. Abundant elements found on the surface of particles sequentially consisting of $\mathrm{O}, \mathrm{Si}, \mathrm{C}, \mathrm{Na}, \mathrm{Al}, \mathrm{K}$ and $\mathrm{Ca}$. The ratio of components $(\mathrm{Ca}$, $\mathrm{C}, \mathrm{O}, \mathrm{Na}, \mathrm{Al}$, Si, and $\mathrm{K})$ found at both places in TSP samples of Jakarta and Puncak-Bogor were 1.303; 1,060; 1,026; 0.995; 0.969; 0.898; and 0.882, respectively. TSP from Puncak-Bogor has a morphology that tends to be irregularly shaped, while TSP from Jakarta tends to be round stacked. Based on its morphology and chemical analysis, most of TSP in Puncak-Bogor originated from natural sources, while TSP in Jakarta came from a mixture of particulates of anthropogenic sources.

Keywords: TSP, pollution-rose, Scanning Electron Microscope (SEM), morphology, anthropogenic.

\section{Pendahuluan}

Pencemaran udara telah menjadi masalah lingkungan secara global (Wang et al., 2019), serta merupakan penyebab utama kematian dan penyakit (Agrawal et al., 2011; López-Ayala et al., 2019). Salah satu polutan udara utama yang mempengaruhi kesehatan manusia adalah partikulat (LongoriaRodríguez et al., 2021; Mico et al., 2015). Partikulat di udara secara operasional dapat diklasifikasikan menjadi beberapa fraksi berdasarkan diameter aerodinamis: misalnya, total partikel tersuspensi (TSP: diameter aerodinamis $\leq 100 \mu \mathrm{m}), \operatorname{PM} 10(\leq 10 \mu \mathrm{m})$, PM2.5 $(\leq 2.5 \mu \mathrm{m})$, dan PM1. $0(\leq 1.0 \mu \mathrm{m})$ (Dai et al., 2016). TSP merupakan komponen sangat penting dari parameter kualitas udara ambien dimana nilai baku mutu udara ambien parameter partikulat debu $<100 \mu \mathrm{m}$ (TSP) dengan waktu pengukuran selama 24 jam adalah $230 \mu \mathrm{g} / \mathrm{m}^{3}$ berdasarkan Peraturan Pemerintah No 41 Tahun 1999. Nilai ini sama dengan baku mutu terbaru yaitu PP No 22 Tahun 2021. TSP umumnya terdiri dari beberapa komponen termasuk partikel tanah tersuspensi, bahan lapuk, abu terbang dan polutan yang dihasilkan kendaraan, dan reaksi kimia atmosfer (Cruz-Campas et al., 2019).

Penentuan komponen kimia dalam materi partikulat merupakan langkah penting untuk meningkatkan pengetahuan tentang asal polutan (Ahmady-Birgani et al., 2015; Hleis et al., 2013). Keberadaan pencemaran partikel di lingkungan dapat dipengaruhi oleh beberapa variabel seperti geografi lokal, meteorologi, angin, dan stabilitas atmosfer (Dai et al., 2016; Ochsenkühn-Petropoulou et al., 2009). Penentuan asal TSP seringkali didasarkan pada karakteristik morfologi dan kimianya (Cruz-Campas et al., 2019; Ramirez-Leal, 2020). Karakteristik fisik dan kimia dari partikel berbeda, karena variabilitas besar sumber emisi, dan proses pembentukan 
dan pasca pembentukan. Informasi tentang ukuran partikel, bentuk dan komposisi unsur sangat penting untuk memahami kontribusi sumber emisi. Data ini tidak dapat diambil hanya dari analisis kimia. Scanning Electron Microscopy (SEM) digabungkan dengan energi spektroskopi sinar-X terdispersi (EDS) menjadikan sebagai alat yang ampuh untuk karakterisasi fisika-kimia dari materi partikulat (Mico et al., 2015; Sonwani \& Kulshrestha, 2018).

Pandemi Covid-19 yang mendunia telah menimbulkan berbagai dampak positif bagi lingkungan dan iklim. Penurunan emisi $\mathrm{CO}_{2}$ harian global diperkirakan sekitar $17 \%$, mencapai tingkat emisi $\mathrm{CO}_{2}$ yang serupa dengan yang terjadi pada tahun 2006. Studi lain menunjukkan penurunan $\mathrm{PM}_{2.5}$ di negara-negara Asia (India, Cina) dan Eropa (Spanyol, Prancis, dan Italia) (Espejo et al., 2020). Penelitian terbaru telah melaporkan peningkatan kualitas udara terkait dengan langkah-langkah dalam menjaga jarak sosial, dan akibat penurunan transit kendaraan pada masa pandemic covid-19. Badan Lingkungan Hidup DKI Jakarta melaporkan bahwa kualitas udara meningkat sejak pemberlakuan jarak fisik, mendesak kantorkantor untuk menghentikan operasional, membatasi pekerjaan dan transportasi umum sejak 23 Maret sebagai bagian dari tindakan tanggap darurat Covid-19. Menurut data badan lingkungan, konsentrasi $\mathrm{PM}_{2.5}$, partikel polutan yang dapat terhirup dengan diameter kurang dari 2,5 mikrometer berada di bawah 40 mikrogram meter kubik turun dari lebih dari $60 \mu \mathrm{g} / \mathrm{m}^{3}$ (Priyo Purnomo et al., 2020). Pengukuran konsentrasi PM10 di Stasiun BMKG Kemayoran pada 13-19 April 2020 menunjukkan dibawah baku mutu yang ditetapkan WHO yaitu $50 \mu \mathrm{g} / \mathrm{m}^{3}$ (Hafidzhah Dyah Ayu Anggraeni et al., 2021). Jenis partikulat TSP hasil pengukurannya akan dibahas dalam kajian ini serta penelitian lanjutan partikulat TSP menarik untuk dilakukan terlebih lagi dengan kondisi pandemik saat ini.
Dalam studi ini ditentukan karakterisasi kimia dan morfologi serta konsentrasi dari partikulat TSP yang berasal dari daerah urban dan urban background/ suburban. Tujuan dari penelitian ini adalah sebagai berikut: menentukan konsentrasi dan tingkatan potensi toksisitas TSP; melakukan karakterisasi kimia dan morfologi dari sampel TSP; dan mengkaji pengaruh PSBB terhadap konsentrasi TSP.

\section{Metodologi}

\subsection{Lokasi}

Sampel TSP dikumpulkan di dua stasiun pemantauan kualitas udara Badan Meteorologi, Klimatologi, dan Geofisika (BMKG). Stasiun pemantauan kualitas udara ini dipilih berdasarkan kelompok wilayah perkotaan dan background. Periode sampling adalah selama 6 hari sekali mulai dari 14 Maret - 19 Mei 2020.

Stasiun Meteorologi Kemayoran merupakan salah satu Unit Pelaksana Teknis (UPT) dari Badan Meteorologi Klimatologi dan Geofisika (BMKG) yang terletak pada koordinat $6,16^{\circ} \mathrm{LS}$ dan $106,84^{\circ} \mathrm{BT}$ serta $4 \mathrm{mdpl}$ (Mahendra Putra et al., 2020). Kemayoran berada di wilayah administrasi Jakarta Pusat yang merupakan pusat ibukota dengan lalu lintas kendaraan yang sangat padat. Stasiun pemantauan kedua terletak di Cibeureum, Puncak-Bogor (6,71 LS, 106,95 BT, $1160.5 \mathrm{mdpl})$, yang berada di kawasan Puncak (daerah pegunungan) (Nishihashi et al., 2019). Lokasi Pos Polusi Udara Cibeureum jauh dari jalur lalu lintas kendaraan sehingga cocok dijadikan sebagai lokasi background.

\subsection{Pengujian Sampel}

Sampel TSP diambil menggunakan alat High Volume Air Sampler yang dioperasikan selama 24 jam, mengacu pada SNI 19-7119.32017 tentang Udara Ambien - Bagian 3: Cara Uji Partikel Tersuspensi Total menggunakan Peralatan High Volume Air Sampler (HVAS) dengan Metode Gravimetri. Jenis filter 
yang digunakan untuk mengumpulkan TSP adalah filter fiberglass berukuran $8 \times 10$ inci. Sebelum dan sesudah pengambilan sampel, filter dikondisikan dalam ruangan dengan kondisi kelembaban yang terkontrol $(<50 \%)$ dan suhu $\left(20-25^{\circ} \mathrm{C}\right)$. Langkah pengerjaan ini dilakukan sesuai SNI 19-7119.3-2017 [BSN, 2017].

Setelah dilakukan pengambilan sampel, konsentrasi TSP dihitung dengan membagi berat bahan yang dikumpulkan dengan volume total sampel udara. Persamaan di bawah ini menunjukkan perhitungan untuk menentukan konsentrasi TSP:

$\operatorname{TSP}\left(\mu \mathrm{g} / \mathrm{m}^{3}\right)=\frac{\text { Berat akhir }(\mathrm{mg}) \text {-berat awal }(\mathrm{mg})}{\text { Flow rate }\left(\frac{\mathrm{m} 3}{\min }\right) \times \text { lama sampling }(\min ) \times 1000}$

Potensi toksisitas dari TSP dapat ditentukan sebagai berikut:

Potensi Toksisitas $=\frac{\text { konsentrasi TSP }}{\text { Nilai Baku Mutu TSP }}$

(Ediagbonya, 2014)

\subsection{Data Klimatologi}

Data klimatologi selama periode sampling didasarkan pada informasi yang diperoleh dari Stasiun Pengamatan BMKG yaitu Stasiun Meteorologi Kemayoran dan Pos Polusi Udara Cibeureum. Data tersebut meliputi data temperatur, kelembaban relatif, curah hujan, dan data angin (arah angin dan kecepatan angin).

\subsection{Karakteristik Kimia dan Morfologi TSP}

Sampel TSP dianalisis dengan Scanning Electron Microscopy (SEM) di Pusat Penelitian Fisika-LIPI. Gambar diperoleh menggunakan mikroskop elektron pemindaian JEOL JSM-IT200, yang dilengkapi dengan penganalisis X-ray Energy Dispersive Spectroscopy (EDS) yang beroperasi pada $10 \mathrm{kV}$. Citra SEM untuk setiap sampel diambil pada lima perbesaran yaitu 500x, 1000x, 2500x, 5000x dan 10000x. Analisis unsur dilakukan dalam mode otomatis dan data disajikan dalam bentuk persen berat atom dan persen massanya. Unsur-unsur yang dipertimbangkan untuk dilakukan analisis semi kuantitatif diantaranya adalah $\mathrm{C}, \mathrm{O}$, $\mathrm{Na}, \mathrm{Al}, \mathrm{Si}, \mathrm{K}$, dan Ca.

\section{Hasil dan Pembahasan}

\subsection{Konsentrasi TSP}

Nilai baku mutu TSP selama 24 jam berdasarkan Peraturan Pemerintah no. 22 Tahun 2021 pada lampiran 7 adalah $230 \mu \mathrm{g} /$ $\mathrm{m}^{3}$. Hasil perhitungan konsentrasi TSP, nilai potensi toksisitas dan data klimatologi dari kedua stasiun pengamatan disajikan pada Tabel 1 dan Tabel 2. Pada Tabel 1, konsentrasi TSP tertinggi di Stasiun BMKG Kemayoran sebesar $174,06 \mu \mathrm{g} / \mathrm{m}^{3}$ dengan nilai ratarata sebesar $121,21 \mu \mathrm{g} / \mathrm{m}^{3}$, sedangkan konsentrasi TSP terendahnya sebesar 65,67 $\mu \mathrm{g} / \mathrm{m}^{3}$. Nilai rata-rata potensi toksisitas TSP di Jakarta sebesar 0,527. Apabila membagi tingkat potensi toksisitas kedalam tiga tingkatan yaitu rendah $(0,01-0,49)$, sedang (0,50-0,99), dan tinggi $(\geq 1)$, maka kualitas udara di Kemayoran membaik dengan nilai potensi toksisitas $<0,50$ atau pada tingkat rendah pada awal April 2020. Hal ini seiring dengan adanya upaya dari pemerintah dalam menghadapi pandemik Covid-19 di Jakarta. Pembatasan Sosial Berskala Besar (PSBB) mulai disosialisasikan dan diberlakukan pada minggu kedua April 2020. Pada awal minggu pertama pemberlakuan PSBB di Jakarta, nilai potensi toksisitasnya sebesar 0,47 dan masih dalam tingkatan rendah. Pada minggu berikutnya nilai potensi toksisitasnya kembali meningkat menjadi $>0,50$ (tingkatan sedang) seiring dengan masa PSBB transisi yang memberi dampak bertambahnya aktivitas antropogenik dibandingkan dengan minggu sebelumnya.

Penerapan lockdown juga dilakukan oleh banyak kota di seluruh dunia yang terkena dampak ini dan berpengaruh secara tidak langsung terhadap tingkat kualitas 
udara yang semakin membaik. Peneliti menyelidiki dampak tindakan tersebut terhadap kualitas udara yang diasumsikan bahwa lebih sedikit orang yang akan mengemudi dan dengan demikian akan ada tingkat polutan udara terkait lalu lintas yang lebih rendah.

Hasil kajian kelompok penelitian di kota-kota besar seperti Sao Paulo, Brasil; Wuhan, Cina; dan Barcelona, Spanyol melaporkan terjadinya penurunan konsentrasi polutan udara terkait lalu lintas dari Januari hingga Mei 2020. Mereka berpendapat bahwa hal ini merupakan hasil dari pengurangan emisi kendaraan. Beberapa penelitian juga menunjukkan penurunan serupa dalam konsentrasi polutan dengan membandingkan konsentrasi yang diukur pada tahun 2020 dibandingkan dengan konsentrasi pada tahun-tahun sebelumnya (Zangari et al., 2020).

Konsentrasi TSP di Stasiun BMKG Cibeureum tertinggi sebesar $81,53 \mu \mathrm{g} / \mathrm{m}^{3}$ dengan nilai rata-rata sebesar $50,62 \mu \mathrm{g} / \mathrm{m}^{3}$, sedangkan konsentrasi TSP terendahnya sebesar 30,74 $\mu \mathrm{g} / \mathrm{m}^{3}$ (Tabel 2). Perbandingan nilai rata-rata konsentrasi TSP yang berasal dari lokasi BMKG Kemayoran jauh lebih besar dibandingkan TSP yang berasal dari stasiun BMKG Cibeureum. Nilai potensi toksisitasnya pun sangat rendah dengan ratarata sebesar 0,22 sehingga dikategorikan

Tabel 1. Konsentrasi TSP dan Nilai Potensi Toksisitas (PT) dan Data Klimatologi Kemayoran

\begin{tabular}{|c|c|c|c|c|c|c|c|}
\hline $\begin{array}{c}\text { Tanggal } \\
\text { Sampling }\end{array}$ & $\begin{array}{c}\text { TSP }(\mu \mathrm{g} / \\
\left.\mathrm{m}^{3}\right)\end{array}$ & PT & $\begin{array}{r}\text { Kecepatan } \\
\text { angin }(\mathrm{m} / \mathrm{s})\end{array}$ & Arah angin & $\begin{array}{c}\text { Suhu udara } \\
\left({ }^{\circ} \mathrm{C}\right)\end{array}$ & $\% \mathrm{RH}$ & $\begin{array}{c}\text { Curah hujan } \\
\text { (mm) }\end{array}$ \\
\hline $14 / 03 / 2020$ & 169,42 & 0,737 & 1,1 & Barat & 29,4 & 79 & 0,0 \\
\hline $20 / 03 / 2020$ & 109,28 & 0,475 & 1,7 & Barat & 27,4 & 83 & 16,0 \\
\hline $26 / 03 / 2020$ & 105,23 & 0,458 & 1,3 & Barat Laut & 28,8 & 78 & 0,0 \\
\hline $01 / 04 / 2020$ & 65,85 & 0,286 & 1,9 & Barat Laut & 28,1 & 80 & 22,0 \\
\hline $07 / 04 / 2020$ & 65,67 & 0,286 & 1,0 & Barat & 28,6 & 77 & 31,0 \\
\hline $13 / 04 / 2020$ & 108,73 & 0,473 & 2,0 & Barat Laut & 27,7 & 90 & 15,0 \\
\hline $19 / 04 / 2020$ & 174,06 & 0,757 & 1,3 & Tenggara & 29,6 & 76 & 0,0 \\
\hline $25 / 04 / 2020$ & $\mathrm{td}$ & $\mathrm{td}$ & 1,1 & Tenggara & 29,1 & 75 & 0,0 \\
\hline $01 / 05 / 2020$ & 167,09 & 0,726 & 0,9 & Barat & 28,8 & 81 & 0,0 \\
\hline $07 / 05 / 2020$ & 148,76 & 0,647 & 1,0 & Barat Laut & 30,2 & 72 & 0,0 \\
\hline $13 / 05 / 2020$ & 117,28 & 0,510 & 1,0 & Barat & 29,9 & 79 & 4,0 \\
\hline $19 / 05 / 2020$ & 101,98 & 0,443 & 1,3 & Barat Laut & 28,7 & 76 & 13,0 \\
\hline
\end{tabular}

*) $\mathrm{td}=$ tidak ada data/sampling

Tabel 2. Konsentrasi TSP dan Nilai Potensi Toksisitas (PT) dan Data Klimatologi Cibeureum

\begin{tabular}{|c|c|c|c|c|c|c|c|}
\hline $\begin{array}{c}\text { Tanggal } \\
\text { Sampling }\end{array}$ & $\begin{array}{c}\mathrm{TSP}(\mu \mathrm{g} / \\
\left.\mathrm{m}^{3}\right)\end{array}$ & PT & $\begin{array}{l}\text { Kecepatan } \\
\text { angin }(\mathrm{m} / \mathrm{s})\end{array}$ & Arah angin & $\begin{array}{c}\text { Suhu udara } \\
\left({ }^{\circ} \mathrm{C}\right)\end{array}$ & $\%$ RH & $\begin{array}{l}\text { Curah hujan } \\
\text { (mm) }\end{array}$ \\
\hline $14 / 03 / 2020$ & 50,72 & 0,221 & 0,5 & Selatan & 21,4 & 85 & 0,0 \\
\hline $20 / 03 / 2020$ & 41,64 & 0,181 & 0,6 & Selatan & 20,5 & 88 & 19,0 \\
\hline $26 / 03 / 2020$ & 30,74 & 0,134 & 0,5 & Barat & 21,0 & 90 & 36,0 \\
\hline $01 / 04 / 2020$ & 31,06 & 0,135 & 0,7 & Selatan & 22,8 & 79 & 26,0 \\
\hline $07 / 04 / 2020$ & 40,98 & 0,178 & 0,6 & Selatan & 22,0 & 80 & 27,0 \\
\hline $13 / 04 / 2020$ & 49,48 & 0,215 & 0,6 & Selatan & 22,2 & 83 & 8,0 \\
\hline $19 / 04 / 2020$ & 81,53 & 0,354 & 0,7 & Selatan & 22,8 & 80 & 26,0 \\
\hline $25 / 04 / 2020$ & 80,00 & 0,348 & 0,5 & Selatan & 22,2 & 69 & 5,0 \\
\hline $01 / 05 / 2020$ & 55,70 & 0,242 & 0,4 & Barat & 21,4 & 92 & 40,0 \\
\hline $07 / 05 / 2020$ & 44,14 & 0,192 & 1,4 & Tenggara & 22,7 & 76 & 3,0 \\
\hline $13 / 05 / 2020$ & 51,23 & 0,223 & 0,7 & Selatan & 22,6 & 85 & 1,0 \\
\hline $19 / 05 / 2020$ & 50,25 & 0,218 & 0,6 & Selatan & 22,4 & 73 & 51,0 \\
\hline
\end{tabular}


Tabel 3. Perbandingan konsentrasi TSP pada lokasi urban background atau suburban dari penelitian lainnya

\begin{tabular}{llll}
\hline Lokasi & Periode & TSP $\left(\mu \mathrm{g} / \mathrm{m}^{3}\right)$ & Referensi \\
\hline Wong Tai Sin, Hong Kong & Jan 1999 - Feb 1999 & 94,9 & (Dai et al., 2016) \\
Book Han, Korea Selatan & Jan. 2010 - Des. 2013 & 47,9 & ((Dai et al., 2016) \\
Selangor, Malaysia & February 2013 & 14,37 & (Khan et al., 2015) \\
Qingyuan, China & Okt. 2016 - Nov. 2016 & 168 & (Wang et al., 2019) \\
Ishikawa, Jepang & Nov. 2019 - Apr. 2020 & 9,7 & (Zhang et al., 2020) \\
Puncak-Bogor, Indonesia & Mar.2020 - Mei 2020 & 50,6 & Study ini \\
\hline
\end{tabular}

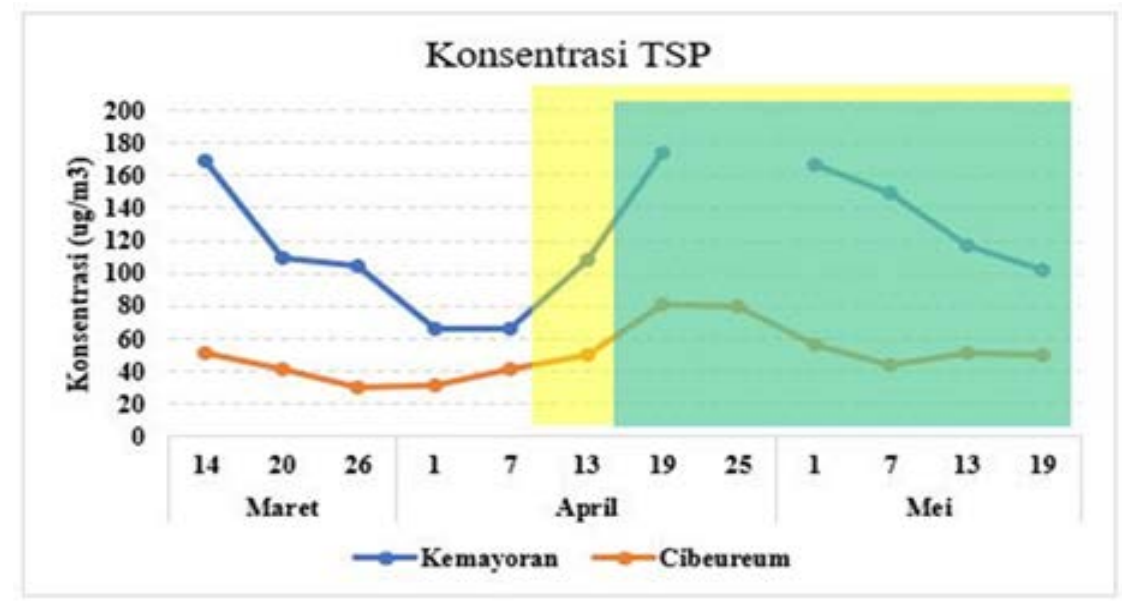

Gambar 1. Konsentrasi TSP selama periode sampling

memiliki kualitas udara yang baik. Berdasarkan nilai konsentrasi TSP, lokasi di Cibeureum dapat dijadikan sebagai lokasi urban background atau suburban.

Berdasarkan Tabel 3. konsentrasi ratarata TSP pada lokasi di BMKG Cibeureum memiliki nilai yang rendah di bawah nilai baku mutu TSP yaitu $230 \mu \mathrm{g} / \mathrm{m}^{3}$. Perbandingan konsentrasi TSP dari literatur yang lain terdapat nilai yang bervariasi TSP yang berasal dari area background dari masing-masing negara. Hal ini dapat terjadi demikian karena dipengaruhi oleh letak wilayah/geografi, faktor meteorologi, angin dan stabilitas atmosfer (Dai et al., 2016).

Adapun pengaruh pelaksanaan PSBB (Kemayoran mulai dari tanggal 10 April 2020 dan Cibueruem 15 April 2020) ternyata berdampak baik bagi lingkungan bila dilihat dari parameter kualitas udaranya. Nilai konsentrasi TSP mengalami tren yang menurun mulai dari akhir bulan maret hingga minggu pertama pelaksanaan PSBB (Gambar 1). Nilai konsentrasi TSP pada awal bulan April 2020, memiliki nilai yang lebih rendah karena selain adanya sosialisasi penerapan PSBB juga terjadinya hujan pada saat periode pengambilan sampel TSP. Rata-rata konsentrasi TSP pada tiga periode sampling pertama bulan April 2020 (menjelang dan awal berlakunya PSBB) memiliki nilai terendah di lokasi Jakarta dan Puncak-Bogor berturut-turut sebesar 80,08 $\mu \mathrm{g} / \mathrm{m}^{3}$ dan $40,51 \mu \mathrm{g} / \mathrm{m}^{3}$. Konsentrasi TSP mengalami peningkatan kembali seiring dengan berlakunya PSBB transisi yaitu dua minggu setelah PSBB pertama diberlakukan. TSP sebagai bagian dari parameter kualitas udara dapat memberikan informasi baik secara fisik maupun kimianya.

Transportasi perpindahan materi partikulat juga dipengaruhi oleh angin. 

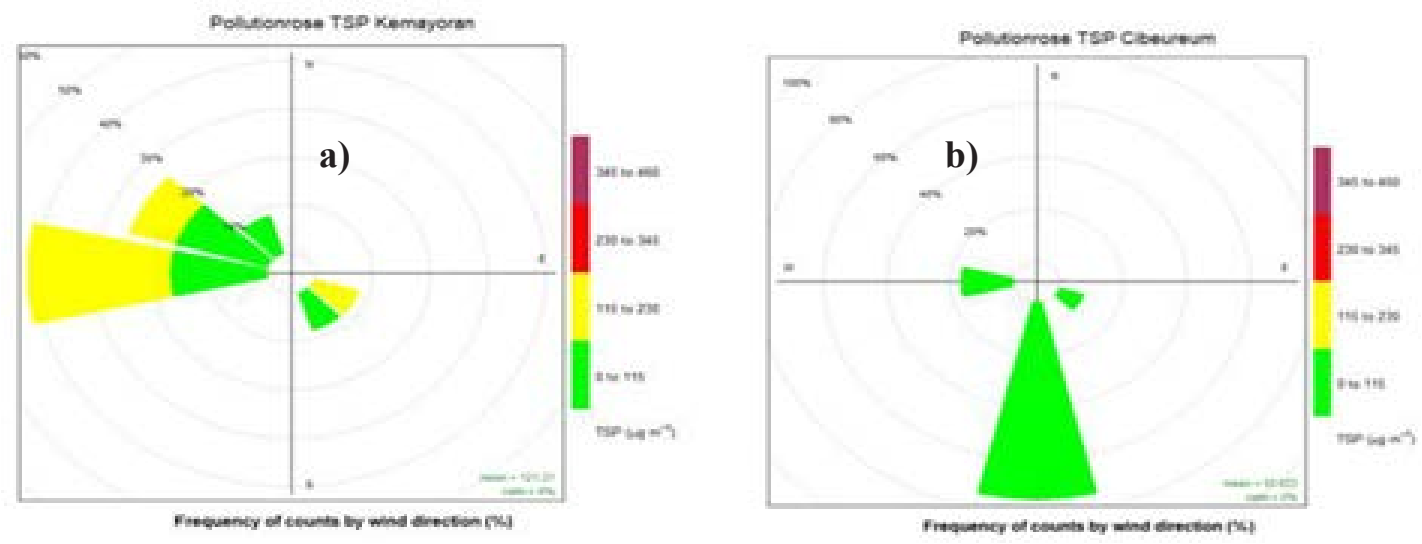

Gambar 2. Pollution-rose TSP: a) Kemayoran; b) Cibeureum

Berdasarkandatagabunganantarakonsentrasi TSP dan data angin (arah dan kecepatan angin), dapat dibuat model sederhana untuk melakukan visualisasi data berupa pollutionrose (Gambar 2). Konsentrasi TSP > $100 \mu \mathrm{g} /$ $\mathrm{m}^{3}$ pada lokasi Kemayoran adalah dominan materi partikulat yang berasal dari arah barat. Kegiatan yang terdapat pada bagian barat dari titik pengambilan sampel TSP, diantaranya adalah lalu lintas yang terdapat di jalan industri, pusat perbelanjaan Mangga Dua, serta hasil pembakaran kendaraan yang melewati tol layang Jakarta Inner Ring Road.

Tingkat materi partikulat yang lebih tinggi di lokasi pengambilan sampel dapat dikaitkan dengan dampak gabungan dari kondisi iklim dan emisi antropogenik oleh berbagai sumber lokal seperti asap kendaraan, pembakaran limbah, dan pembakaran biomassa (Pachauri et al., 2013).

\subsection{Analisis Scanning Electron Microscopy}

\section{(SEM)}

SEM adalah metode untuk pencitraan permukaan resolusi tinggi. Alat ini menggunakan berkas elektron untuk pencitraan permukaan. Keunggulannya dibandingkan mikroskop cahaya adalah pembesaran yang lebih besar dan kedalaman bidang yang jauh lebih besar. Elemen yang berbeda dengan topografi permukaan yang berbeda memancarkan jumlah elektron yang berbeda karena kontras dalam mikrograf SEM mewakili topografi permukaan dan distribusi komposisi elemen di permukaan (Pipal et al., 2011). SEM menawarkan kemungkinan untuk menghubungkan secara visual morfologi, ukuran, dan tekstur partikel atmosfer dengan komposisi kimia yang sesuai yang ditentukan secara semikuantitatif oleh Spektroskopi Sinar-X dispersif energi (EDS) (González et al., 2016).

Struktur partikel bisa beragam dan biasanya menampilkan aspek dua dimensi. Seringkali ditemukan bahwa partikelpartikel tersebut memiliki morfologi yang tidak beraturan, tepi luar dan garis-garis rekahan. Unsur-unsur yang ditemukan dalam karakterisasi kimiawi terutama terkait dengan sumber dari tanah, pembakaran, kegiatan pembakaran dan lalu lintas kendaraan (Cruz-Campas et al., 2019). Gambar 3. menunjukkan pemetaan kimiawi dari sampel TSP yang dikumpulkan di lokasi Kemayoran dan Cibeureum. Partikelpartikel tersebut menunjukkan morfologi yang sangat bervariasi. Banyak dari partikel berbentuk bola atau spheriodal, sementara yang lain menampilkan belahan dan ciri khas bahan kristal. Partikel kecil dengan morfologi yang tidak beraturan juga diamati.

Kandungan mineral yang terdapat dalam TSP diantaranya adalah Calcite 
$\left(\mathrm{CaCO}_{3}\right), \quad$ Quartz $\left(\mathrm{SiO}_{2}\right), \quad$ Gypsum $\left(\mathrm{CaSO}_{4} \cdot 2 \mathrm{H}_{2} \mathrm{O}\right)$, Halite $(\mathrm{NaCl})$, dan Alumina $\left(\mathrm{Al}_{2} \mathrm{O}_{3}\right)$ (Ahmady-Birgani et al., 2015; González et al., 2016; Longoria-Rodríguez et al., 2021). Atas dasar tersebut, komponen unsur yang diamati pada EDS meliputi kalsium (Ca), karbon (C), oksigen (O), silika $(\mathrm{Si})$, natrium $(\mathrm{Na})$, alumunium $(\mathrm{Al})$ serta secara default unsur kalium (K) juga diamati. Berdasarkan intensitas warna yang sesuai dengan masing-masing unsur dan kelimpahan relatifnya, pemetaan kimia menunjukkan bahwa unsur yang paling melimpah (\%At) dalam partikel yang terkumpul adalah sebagai berikut: O (49,63\% dan 49,09\%), Si (12,53\% dan $14,17 \%), C$ (29,71\% dan 28,44\%), dan lebih sedikit proporsi unsur dari $\mathrm{Na}(4,96 \%$ dan $5,06 \%)$, Al (1,58\% dan 1,65\%), K (0,92\% dan $1,07 \%)$, dan $\mathrm{Ca}(0,67 \%$ dan $0,52 \%)$ yang terdeteksi (Gambar 3.). Rasio komponen antara Kemayoran-Jakarta dan CibeureumPuncak (Ca, C, O, Na, Al, Si, dan K) masingmasing sebesar 1,303; 1,060; 1,026; 0,995; 0,969; 0,898; dan 0,882. Rasio komponen yang paling mudah untuk dipelajari adalah jumlah karbon yang terkandung dalam TSP dari Kemayoran lebih banyak dibandingkan dengan TSP yang berasal dari Cibeureum. Jejak karbon dapat dijadikan sebagai indikator pencemaran udara yang berasal dari aktivitas antropogenik terutama hasil pembakaran pada kendaraan bermotor. TSP yang berasal dari Cibeureum memiliki kandungan silika dan oksigen yang lebih tinggi dibandingkan dengan TSP dari lokasi Kemayoran. Mineral alumunium silikat dan tanah lempung mungkin terdapat pada sampel TSP dari lokasi Cibeureum yang bersumber dari alam.

Keberadaan Si dan O yang melimpah mungkin terkait dengan mineral Quartz $\left(\mathrm{SiO}_{2}\right)$. Unsur $\mathrm{C}$ yang melimpah dan terdapat unsur $\mathrm{Ca}$ juga bisa terkait dengan mineral Calsite $\left(\mathrm{CaCO}_{3}\right)$. Terdeteksinya unsur Al juga mungkin terkait dengan mineral alumina $\left(\mathrm{Al}_{2} \mathrm{O}_{3}\right)$. Keberadaan natrium juga mungkin dapat dikaitkan dengan mineral Halite $(\mathrm{NaCl})$. Mineral-mineral tersebut juga terdapat pada sampel yang dilakukan oleh beberapa penelitian (González et al., 2016; Longoria-Rodríguez et al., 2021; Ochsenkühn-Petropoulou et al., 2009). Informasi kandungan unsur yang terdapat dalam sampel TSP tersebut menggambarkan perbandingan rasio dari dua lokasi yang berbeda dan juga memperkirakan kemungkinan sumber polutan yang mempengaruhi kualitas udara.

Berdasarkan morfologi dan analisis kimianya dua kelas partikel utama terdeteksi, alami dan antropogenik. Partikel alam sebagian besar terdiri dari partikel debu tanah (mineral) dan biogenik. Partikel tanah memiliki bentuk tidak beraturan dan permukaan kasar dan terkadang membentuk agregat dengan bentuk dan ukuran tidak beraturan, sedangkan partikel biogenik sangat terstruktur, dengan bentuk bulat dan permukaan halus. Partikel antropogenik yang dipancarkan dari proses pembakaran sebagian besar berbentuk bulat dan bulat dengan permukaan halus (Mico et al., 2015).

Hasil fotomikrograf SEM dari sampel TSP Kemayoran maupun Cibeureum memiliki kandungan $\mathrm{Si}$ dan $\mathrm{O}$ yang tinggi sehingga bentuk morfologinya tidak beraturan di sekelilingnya (Gambar 4). Potensi kandungan $\mathrm{Si}$ dan $\mathrm{O}$ yang terdapat pada Glass Fiber Filter (GFF) sebagai media pengumpulan sampel TSP dapat terukur dalam EDS. Namun, untuk mengetahui kandungan $\mathrm{Si}$ dan $\mathrm{O}$ dari sampel TSP diperlukan pengukuran GFF-blanko menggunakan SEM-EDS. TSP Cibeureum memiliki kandungan $\mathrm{Al}$ yang sedikit lebih banyak dengan morfologi yang tidak beraturan. Hal ini menunjukkan sumber TSP di Cibeureum erat juga hubungannya dengan partikel tanah karena dengan keberadaan unsur alumunium dapat membentuk aluminium silikat yang dapat berupa $f l y$ ash atau partikel tanah.TSP kemayoran terdapat campuran bentuk partikulat dengan 
MG1

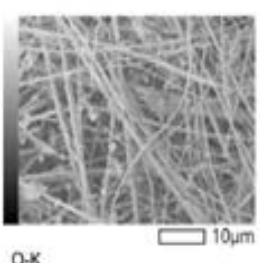

$0-k$

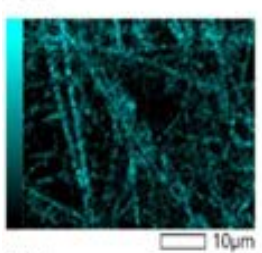

Si-K

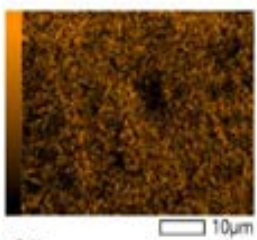

$\mathrm{C}-\mathrm{K}$

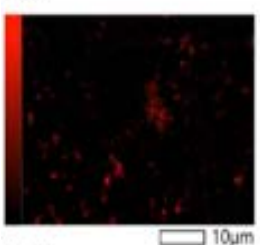

Na-K

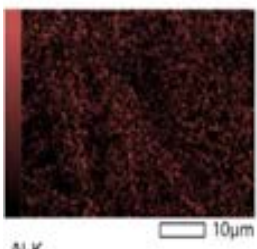

AN-K

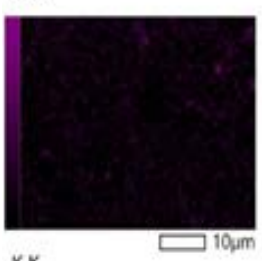

K.K.

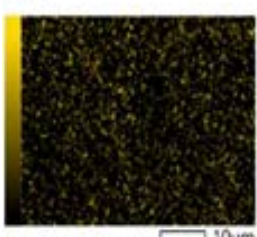

Ca-k

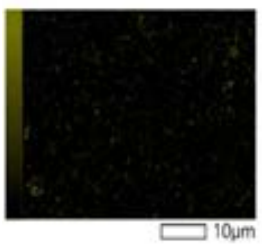

MG1

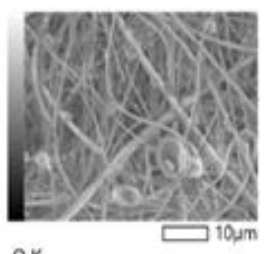

o-K

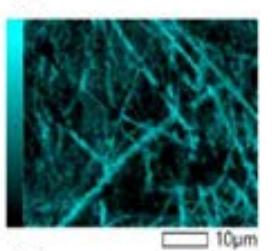

Si-K

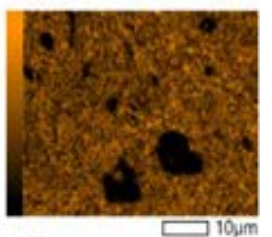

C-K

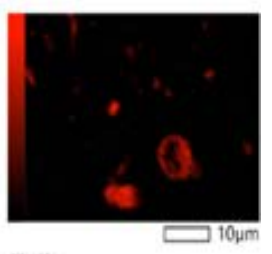

No-K

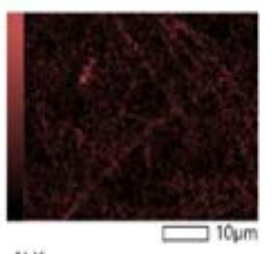

A. K

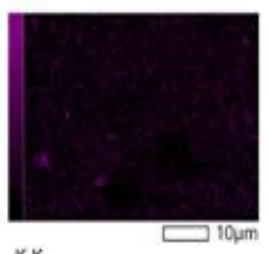

K.K

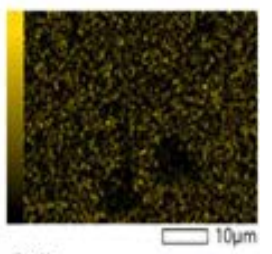

Ca-k

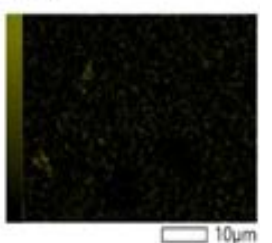

Gambar 3. Pemetaan unsur kimia dari TSP KMY (Kemayoran) dan CBR (Cibeureum) 


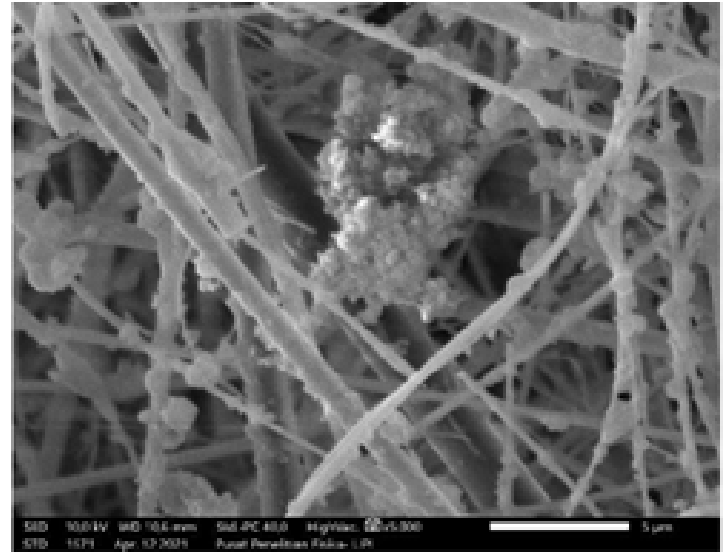

a)

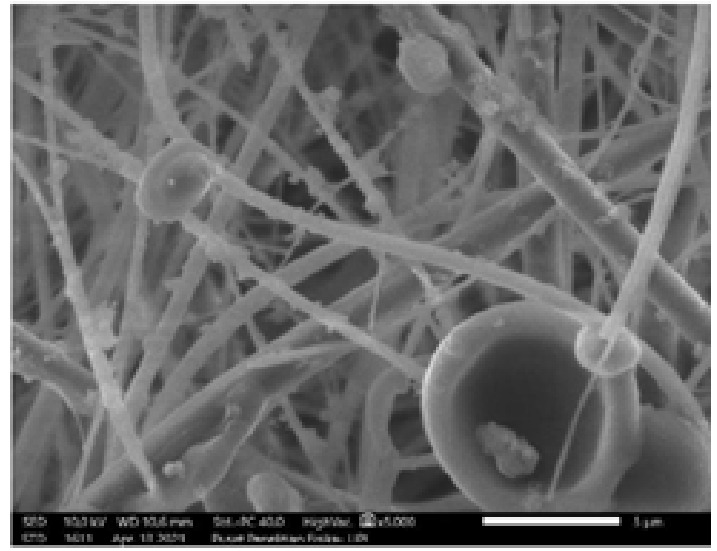

b)

Gambar 3. Pemetaan unsur kimia dari TSP KMY (Kemayoran) dan CBR (Cibeureum)

morfologi yang cenderung beraturan atau bulat tetapi bertumpuk sehingga perlu dilakukan analisis lanjutan untuk mengetahui unsur yang lainnya. Lokasi Kemayoran terdapat di daerah perkotaan dapat diduga dalam sampel TSP terdapat unsur lainnya berupa logam hasil kegiatan antropogenik baik yang berasal dari hasil pembakaran bahan bakar fosil dan dari emisi kegiatan industri. (Pachauri et al., 2013).

\section{Simpulan}

Pada masa sosialisasi dan pemberlakuan PSBB tahap awal, tren konsentrasi TSP mengalami penurunan. Rata-rata konsentrasi TSP pada tiga periode sampling pertama bulan April 2020 memiliki nilai terendah di Kemayoran-Jakarta dan Puncak-Bogor berturut-turut $80,08 \mu \mathrm{g} /$ $\mathrm{m}^{3}$ dan $40,51 \mu \mathrm{g} / \mathrm{m}^{3}$, dibandingkan nilai rata-rata konsentrasi TSP pada tiga periode sebelumnya dan tiga periode setelahnya. Nilai rata-rata potensi toksisitas TSP di lokasi Kemayoran-Jakarta adalah 0,527 (kategori sedang) dan di lokasi PuncakBogor sebesar 0,220 (kategori rendah). Sumber dari asal polutan diprediksi dengan menggunakan model pollution-rose, dimana polutan di Kemayoran-Jakarta didominasi polutan dari arah barat, sedangkan di Puncak-
Bogor didominasi oleh polutan yang berasal dari arah selatan. Hasil karakterisasi kimia sampel TSP yang berasal dari KemayoranJakarta memiliki kandungan karbon yang lebih tinggi, sedangkan sampel TSP dari Puncak-Bogor memiliki kandungan silika dan oksigen yang lebih melimpah. Secara keseluruhan rasio komponen unsur $(\mathrm{Ca}$, $\mathrm{C}, \mathrm{O}, \mathrm{Na}, \mathrm{Al}, \mathrm{Si}$, dan $\mathrm{K}$ ) yang terdapat pada TSP dari lokasi Kemayoran-Jakarta dan Puncak-Bogor berturut-turut 1,303; 1,$060 ; 1,026 ; 0,995 ; 0,969 ; 0,898$, dan 0,882 . Bentuk morfologi TSP dari lokasi Kemayoran-Jakarta adalah berbentuk cenderung beraturan/bulat bertumpuk dan diperkirakan polutan didominasi dari hasil kegiatan antropogenik. TSP dari lokasi Puncak-Bogor morfologinya cenderung tidak beraturan dan diperkirakan dominan polutan yang bersumber dari alam.

\section{Ucapan Terima Kasih}

Penulis mengucapkan terimakasih kepada kepala Stasiun Meteorologi Kemayoran dan Cibeureum, serta Koordinator Laboratorium Kualitas Udara Badan Meteorologi, Klimatologi, dan Geofisika (BMKG) yang telah memfasilitasi dalam sarana dan prasarana dalam pengujian, serta kepada Badan Riset dan 
Inovasi Nasional dalam Program Belajar Berbasis Riset (degree by research-LIPI) yang telah membantu dalam pendanaan penelitian ini. Penulis juga berterimakasih kepada tim Editor dan Mitra Bestari yang telah memberikan masukan dalam penulisan ini.

\section{Kepengarangan}

Penulis pertama melakukan kegiatan pengujian, pengolahan data, dan penyusunan naskah, sementara Penulis kedua dan Penulis ketiga memberikan kontribusi saran dalam pengujian dan penyusunan naskah. Seluruh penulis merupakan suatu kesatuan tim tak terpisahkan yang memberikan kontribusi dalam tiap bagiannya.

\section{Daftar Pustaka}

Agrawal, A., Upadhyay, V. K., \& Sachdeva, K. (2011). Study of aerosol behavior on the basis of morphological characteristics during festival events in India. Atmospheric Environment, 45(21), 3640-3644. https:// doi.org/10.1016/j.atmosenv.2011.04.006.

Ahmady-Birgani, H., Mirnejad, H., Feiznia, S., \& McQueen, K. G. (2015). Mineralogy and geochemistry of atmospheric particulates in western Iran. Atmospheric Environment, 119, 262-272. https://doi.org/10.1016/j. atmosenv.2015.08.021.

Cruz-Campas, M., Ramirez-Leal, R., \& Lopez-Perez, N. (2019). TSP Analysis Performed by SEM-EDS to Air Quality Studies. Microscopy and Microanalysis, 25(S2), 768-769. https://doi.org/10.1017/ s1431927619004574.

Dai, J., Kim, K. H., Dutta, T., Park, W. M., Hong, J. K., Jung, K., \& Brown, R. J. C. (2016). Monitoring of airborne particulate matter at mountainous urban sites. Environmental Monitoring and Assessment, 188(8). https://doi.org/10.1007/s10661-016-55012.

Ediagbonya, T. F. (2014). Analysis of Seasonal Variation of Atmospheric Total Suspended Particulate in Sapele (Urban Area) of Delta State, Nigeria. In Nigerian Journal of
Scientific Research (Vol. 13, Issue 1).

Espejo, W., Celis, J.E., Chiang, G., \& Bahamonde, P. (2020). Environment and COVID-19: Pollutants, impacts, dissemination, management and recommendations for facing future epidemic threats. Science of the Total Environment, 747. https://doi. org/10.1016/j.scitotenv.2020.141314.

González, L. T., Rodríguez, F. E. L., SánchezDomínguez, M., Leyva-Porras, C., SilvaVidaurri, L. G., Acuna-Askar, K., Kharisov, B. I., Villarreal Chiu, J. F., \& Alfaro Barbosa, J. M. (2016). Chemical and morphological characterization of TSP and PM2.5 by SEM-EDS, XPS and XRD collected in the metropolitan area of Monterrey, Mexico. Atmospheric Environment, 143. https://doi. org/10.1016/j.atmosenv.2016.08.053.

Hafidzhah Dyah Ayu Anggraeni, S., Hanani Darundiati, Y., \& Joko, T. (2021). Analisis Konsentrasi PM10 Hasil Pengukuran Stasiun BMKG Kemayoran di Jakarta Pusat Pada Masa Pandemi COVID-19. Media Kesehatan Masyarakat Indonesia. https://doi.org/10.14710/mkmi.20.1.63-69.

Hleis, D., Fernández-Olmo, I., Ledoux, F., Kfoury, A., Courcot, L., Desmonts, T., \& Courcot, D. (2013). Chemical profile identification of fugitive and confined particle emissions from an integrated iron and steelmaking plant.JournalofHazardous Materials, 250-251, 246-255. https://doi. org/10.1016/j.jhazmat.2013.01.080.

Khan, M. F., Latif, M. T., Amil, N., Juneng, L., Mohamad, N., Nadzir, M. S. M., \& Hoque, H. M. S. (2015). Characterization and source apportionment of particle number concentration at a semi-urban tropical environment. Environmental Science and Pollution Research, 22(17), 13111-13126. https://doi.org/10.1007/s11356-015-45414.

Longoria-Rodríguez, F. E., González, L. T., Mancilla, Y., Acuña-Askar, K., ArizpeZapata, J. A., González, J., Kharissova, O. v., \& Mendoza, A. (2021). Sequential SEM-EDS, PLM, and MRS microanalysis of individual atmospheric particles: A useful tool for assigning emission sources. Toxics, 9(2), 1-22. https://doi.org/10.3390/ toxics 9020037 . 
López-Ayala, O., González-Hernández, L. T., Alcantar-Rosales, V. M., Elizarragaz-de la Rosa, D., Heras-Ramírez, M. E., SilvaVidaurri, L. G., Alfaro-Barbosa, J. M., \& Gaspar-Ramírez, O. (2019). Levels of polycyclic aromatic hydrocarbons associated with particulate matter in a highly urbanized and industrialized region in northeastern Mexico. Atmospheric Pollution Research, 10(5), 1655-1662. https://doi.org/10.1016/j.apr.2019.06.006.

Mahendra Putra, R., Anjar Rani, N., Bidang Manajemen Observasi Meteorologi Permukaan, S., \& Meteorologi Klimatologi dan Geofisika, B. (2020). Prediksi Curah Hujan Harian di Stasiun Meteorologi Kemayoran Menggunakan Artificial Neural Network (ANN) (Vol. 1).

Mico, S., Tsaousi, E., Deda, A., \& Pomonis, P. (2015). Characterization of Airborne Particles And Source Identification Using SEM/EDS. Chem. Bull, 4(4), 224-229. https://doi.org/10.17628/ECB.2015.4.224.

Nishihashi, M., Mukai, H., Terao, Y., Hashimoto, S., Osonoi, Y., Boer, R., Ardiansyah, M., Budianto, B., Immanuel, G. S., Rakhman, A., Nugroho, R., Suwedi, N., Rifai, A., Ihsan, I. M., Sulaiman, A., Gunawan, D., Suharguniyawan, E., Nugraha, M. S., Wattimena, R. C., \& Ilahi, A. F. (2019). Greenhouse gases and air pollutants monitoring project around Jakarta megacity. IOP Conference Series: Earth and Environmental Science, 303(1). https:// doi.org/10.1088/1755-1315/303/1/012038.

Ochsenkühn-Petropoulou, M., Lyberopoulou, T., Argyropoulou, R., Tsopelas, F., \& Ochsenkühn, K.-M. (2009). Chemical and Structural Characterization of Airborne Particulate Matter In An Industrial and An Urban Area In Greece. https://www. researchgate.net/publication/230720567.

Pachauri, T., Singla, V., Satsangi, A., Lakhani, A., \& Maharaj Kumari, K. (2013). SEMEDX characterization of individual coarse particles in Agra, India. Aerosol and Air Quality Research, 13(2), 523-536. https:// doi.org/10.4209/aaqr.2012.04.0095.

Peraturan Pemerintah no 22 Tahun 2021 tentang Penyelenggaraan Perlindungan dan Pengelolaan Lingkungan Hidup, Lampiran 7. (2021).

Pipal, A. S., Kulshrestha, A., \& Taneja, A. (2011). Characterization and morphological analysis of airborne PM2.5 and PM10 in Agra located in north central India. Atmospheric Environment, 45(21), 3621-3630. https://doi.org/10.1016/j. atmosenv.2011.03.062.

Priyo Purnomo, E., Dzinnun, Y., \& Salsabila, L. (2020). Restriction On Public Transportation Reface A Quality Air Pollution Index During Covid-19 In Indonesia And Thailand. Vol. 17 No. 8 (2020): PalArch's Journal of Archaeology of Egypt/Egyptology.

Ramirez-Leal, R. (2020). Elemental Morphological and Chemical Characterization of Individual TSP Particles by SEM-EDS. Microscopy and Microanalysis, 26(S2), 2202-2204. https:// doi.org/10.1017/s1431927620020796.

Wang, T., Rovira, J., Sierra, J., Chen, S. J., Mai, B. X., Schuhmacher, M., \& Domingo, J. L. (2019). Characterization and risk assessment of total suspended particles (TSP) and fine particles (PM2.5) in a rural transformational e-waste recycling region of Southern China. Science of the Total Environment, 692, 432-440. https://doi. org/10.1016/j.scitotenv.2019.07.271.

Zangari, S., Hill, D. T., Charette, A. T., \& Mirowsky, J. E. (2020). Air quality changes in New York City during the COVID-19 pandemic. Science of the Total Environment, 742. https://doi. org/10.1016/j.scitotenv.2020.140496.

Zhang, L., Yang, L., Zhou, Q., Zhang, X., Xing, W., Zhang, H., Toriba, A., Hayakawa, K., \& Tang, N. (2020). Impact of the COVID-19 outbreak on the long-range transport of particulate pahs in east asia. Aerosol and Air Quality Research, 20(10), 2035-2046. https://doi.org/10.4209/aaqr.2020.07.0388. 